\title{
Analysis on building construction project cost
}

\author{
Yilin LIU, Mei LU
}

$\mathrm{Xi}^{\prime}$ an University of Architecture and Technology Management College, Xi' an China 710055

Xi' an University of Architecture and Technology, Management College, Xi' an China 710055 272999530@qq.com, 1822831317@qq.com

Keywords: construction project, cost

Abstract. Optimization of construction scheme for the contractor to improve the competitiveness of the contracted project, the increase of project profit plays an important role, and the optimization scheme aims to ensure the project quality, schedule and safety goals are achieved at the same time, reduce the cost of contractor construction. Firstly, using the method of principal component analysis for the main index of the construction scheme and their mutual influence relations, and on the basis of the main indicators of the evaluation index system is established, get more efficient methods of the Contractor's construction cost control.

\section{The structure of the composition of architectural engineering construction cost}

Building construction costs include wages and the cost of materials and mechanical royalties form.

Indirect cost is the cost of preparations for construction, organize the construction, operation and management services company. Contain the social security fee, housing fund,accident insurance, general and administrative expenses,travel and transportation expenses etc.

Table1 Main economic indicators of general contracting construction enterprises

\begin{tabular}{|c|c|c|c|c|c|}
\hline & Number of & $\begin{array}{c}\text { The total } \\
\text { output value of } \\
\text { construction } \\
\text { industry } \\
\text { enterprises }\end{array}$ & $\begin{array}{c}\text { The total } \\
\text { profits and } \\
\text { taxes }\end{array}$ & Cost & Cost ratio \\
\cline { 2 - 6 } & & (million) & (million) & (million) & $\%$ \\
\hline 2011 & 40480 & 1043602671 & 69711309 & 973891362 & $93.32 \%$ \\
\hline 2010 & 39430 & 851547281.5 & 58332626 & 793214656 & $93.15 \%$ \\
\hline 2008 & 38375 & 679645883.8 & 46156729 & 633489154 & $93.21 \%$ \\
\hline 2007 & 38212 & 542268099.5 & 37837326 & 504430774 & $93.02 \%$ \\
\hline
\end{tabular}

From 2007 to 2010 data point of view, over the years the construction industry enterprises accounted for $93 \%$ of total production value of cost. To reduce the cost is the key to ensure good operation of construction enterprises (The above data from China Statistical Yearbook )

\section{The general factors influencing the construction cost of housing construction project}

(1)The cultural quality of workers

Labor subcontracting enterprises workers mainly from migrant workers team,at present mainly are 20-40 year old young male migrant workers who work in the most grass-roots of the construction industry.Their quality and work ability directly affects all the engineering 
quality,safety,schedule and cost etc.The rural transfer labor as a whole with low cultural level and low human capital,so most of them have low-skill jobs and less stable.32.7\% of migrant workers experienced training skills,according to the 2013 national migrant workers monitoring report of State Statistical Bureau released.

(2)Risk factors

Labor cost rise: worker pay are increasing in the construction industry with the gradual increase in prices. But ,generally the labor price confirmation is according to unit size or national quota of artificial man days,under the condition of certain expense,wage increases for workers is no doubt very important factors to increase the cost of total cost.

Laying-off:the contractor can put forward claims with owner when encounter laying-off caused by non-construction, but it is difficult to find when needs a large number of workers to return to work.That is the most of problem of labor cost.

(3) Management factors

Rigorous performance appraisal system,grasp the time discontinuous construction workers,reasonably arrange the construction contents and working procedure,effective communication with external parties,shorten the construction period greatly,all of this can reduce labor costs.

\section{Sort of considerations}

In order to find out the main factors of the service subcontracting costs,according to practical situation ,on the basis of common factors,using the method of principal component analysis the main factors of service subcontracting costs and summarized.

\section{Analysis of common factors}

In order to identify the main factors of service subcontracting costs,sorting out the general factors of service subcontracting costs by investigating and analyzing,as shown in Table 2.

Table 2 The general active factors of costs of service subcontracting costs

\begin{tabular}{|c|l|}
\hline Number & \multicolumn{1}{|c|}{ Content } \\
\hline 1 & $\begin{array}{l}\text { Form of contract price of service subcontract (include unit rate } \\
\text { contract,fixed-price contract etc) }\end{array}$ \\
\hline 2 & Job site and production and living conditions \\
\hline 3 & The management of workers \\
\hline 4 & The ability of workers \\
\hline 5 & Job term and schedule requirements \\
\hline 6 & Adjust of service price \\
\hline 8 & $\begin{array}{l}\text { Security and accident insurance and compensation } \\
\text { subcontractor) }\end{array}$ \\
\hline 9 & The amount change of jobs and temporary services \\
\hline 10 & Supply and storage of materials and equipment \\
\hline 11 & $\begin{array}{l}\text { Loss of property caused by the adverse working conditions and force } \\
\text { majeure }\end{array}$ \\
\hline
\end{tabular}

\section{Research methods and data sources}

I found 12 common active factors and use the method of questionnaire investigation to study the 
degree of these factors,utilize principal component analysis and SPSS19.0 software to analysis the interrelated data by recovered questionnaires.Finally find out the main factors of costs.

A total of 100 copies of questionnaires were provide, and 87 copies were collected. the valid questionnaires are 62 and account for $86.6 \%$ of collected,provide effective and reliable data for study.

\section{Data analysis}

(1) To construct the correlation matrix.

Through the questionnaire obtained common factors as 1-5,according to the effective investigation results achieved,a total of 62 samples and each sample of 12 variables were evaluated,therefore constitute the correlation matrix $m * n(m=62, n=12)$,specific form as follows:

$$
\mathrm{X}=\left[\begin{array}{cccc}
a_{11} & a_{12} & \ldots & a_{1 n} \\
a_{21} & a_{22} & \ldots & a_{2 n} \\
\cdot & \cdot & & \cdot \\
\cdot & \cdot & \ldots & \cdot \\
\cdot & \cdot & & \cdot \\
a_{m 1} & a_{m 2} & \ldots & a_{m n}
\end{array}\right]
$$

(2) Utilize the principal component analysis of correlation matrix

Analyzing above data with SPSS software,obtain eigenvalues, \% of variance,cumulative \%.

Table 3 Total Variance Explained

\begin{tabular}{|l|c|c|c|}
\hline \multirow{2}{*}{ Component } & \multicolumn{3}{|c|}{ Initial Eigenvalues } \\
\cline { 2 - 4 } 1 & Total & \% of Variance & Cumulative \% \\
\hline 2 & 4.415 & 36.792 & 36.792 \\
\hline 3 & 3.190 & 26.581 & 63.373 \\
\hline 4 & 1.614 & 13.452 & 76.826 \\
\hline 5 & 1.125 & 9.376 & 86.201 \\
\hline 6 & .691 & 5.761 & \\
\hline 7 & .447 & 3.722 & \\
\hline 8 & .209 & 1.744 & \\
\hline 9 & .161 & 1.338 & \\
\hline 10 & .073 & .609 & \\
\hline 11 & .051 & .429 & \\
\hline 12 & .021 & .178 & \\
\hline
\end{tabular}

From table 3,we know the eigenvalues of four factors are greater than 1,the eigenvalues are 4.415,3.190,1.614,1.125.

$\%$ of variance are $36.792 \%, 26.581 \%, 13.452 \%, 9.376 \%$.cumulative $\%$ are $82.201 \%$, that can completely described the related factors.

(3) Eigenvector calculate

$\lambda_{1}=4.415, \lambda_{2}=3.190, \lambda_{3}=1.614, \lambda_{4}=1.125$, these are the Eigenvalues of the prior four main component,find out egenvector respectively and named $\mathrm{e}_{1}, \mathrm{e}_{2}, \mathrm{e}_{3}, \mathrm{e}_{4}$, and obtain component matrix, as shown in Table 4. 
Table 4. Main Component Matrix

\begin{tabular}{|c|c|c|c|c|c|}
\hline \multirow{2}{*}{$\begin{array}{l}\text { Serial } \\
\text { Number }\end{array}$} & Variable Name & \multicolumn{4}{|c|}{ Component } \\
\cline { 3 - 6 } & & 1 & 2 & 3 & 4 \\
\hline 1 & $\begin{array}{c}\text { Form of contract price (include unit } \\
\text { rate contract,fixed-price contract etc) }\end{array}$ & 0.684 & -0.479 & -0.244 & 0.021 \\
\hline 2 & $\begin{array}{c}\text { Job site and production and living } \\
\text { conditions }\end{array}$ & 0.824 & 0.141 & 0.136 & -0.218 \\
\hline 3 & The management of workers & 0.206 & 0.134 & 0.763 & -0.222 \\
\hline 4 & The ability of workers & 0.317 & 0.442 & 0.634 & 0.124 \\
\hline 5 & Job term and schedule requirements & 0.683 & -0.439 & 0.475 & -0.237 \\
\hline 6 & Adjust of service price & 0.318 & 0.784 & 0.277 & 0.091 \\
\hline 7 & $\begin{array}{l}\text { Security and accident insurance and } \\
\text { compensation }\end{array}$ & 0.328 & 0.202 & 0.854 & 0.255 \\
\hline 8 & $\begin{array}{l}\text { Delay job term(respective } \\
\text { responsibility bear by contractor and } \\
\text { subcontractor) }\end{array}$ & 0.737 & -0.528 & 0.023 & 0.281 \\
\hline 9 & $\begin{array}{c}\text { The amount change of jobs and } \\
\text { temporary services }\end{array}$ & 0.176 & 0.859 & -0.080 & -0.293 \\
\hline 10 & $\begin{array}{l}\text { Supply and storage of materials and } \\
\text { equipment }\end{array}$ & 0.331 & 0.427 & -0.133 & 0.802 \\
\hline 11 & $\begin{array}{l}\text { Loss of property caused by the } \\
\text { adverse working conditions and } \\
\text { force majeure }\end{array}$ & 0.565 & -0.740 & -0.239 & 0.079 \\
\hline 12 & Suspend of job & 0.618 & 0.366 & -0.352 & -0.262 \\
\hline
\end{tabular}

\section{Conclusion}

As the main component matrix,there are large variables in each factor,the numerical shows the correlation between these variable and factors,so it can be attributed to the following four categories that the main factors of service subcontracting costs. As long as the focus on control can control the housing construction cost of the following factors.

(1)Main component 1: The signing of the contract.Form of contract price ,job site and production and living conditions,job term and schedule requirements, delay in job term,loss of property caused by the adverse working conditions and force majeure,suspend of job,the load values of these factors are larger,they are $0.864,0.824,0.683,0.737,0.565,0.618$ respectively,these variables can be constraint.That signed and related terms is one of the main factors in the costs.

(2)Main component 2:adjust of service price and the amount change of jobs.Adjust of service price and the amount change of jobs and temporary services,the load values of these factors are larger,they are $0.784,0.859$ respectively,the two variables can named the change of price and amount.That the change of price and amount is one of the main factors in the costs.

(3)Main component 3:the ability and security of workers.The management of workers,the ability of workers,security and accident insurance and compensation, the load values of these factors are larger,they are 0.763,0.634,0.854 respectively, the three variables can named the ability and security of workers. That the ability and security of workers is one of the main factors in the costs.

(4)Main component 4:supply and storage of materials and equipment.the load values of the factors are 0.802 . That the supply and storage of materials and equipment is one of the main factors in the service subcontracting costs.

The conclusions drawn from such an analysis are the signing of the contract and a number of specific content are fundamental of service subcontracting costs in the process of 
subcontracting.The second is the adjust of service price and the amount change of jobs and the level of management and technical staff.The last is supply and storage of materials and equipment.The four point is the main active factors of the cost of service subcontracting costs.

\section{References}

[1] Yueliang Jin, The research of service subcontract and bargaining mechanism of construction[D].Chengdu sichuan,Southwest Jiaotong University.2008.

[2] jing Liu,The research on construction labor institutional change and countermeasures [D],Xi'an Shannxi,Xi'an university of architecture and technology,2010.

[3] Daojuan Liu,The research of security situation and strategies of management of construction enterprises in Chongqing[D],Chongqing,Chongqing University,2010.

[4] Chao Yang, Exploration of the internal contractor model of construction project of $\mathrm{J}$ company[D], Nanchang,Jiangxi.Nanchang University.2010

[5] Yuehui Liu, The research on the problem of labor and employment management of zhongguobaye [D],Lanzhou,Gansu,Lanzhou University.2011

[6] Libin Huan,The analysis of current situation of service subcontract and development in construction industry[D],Xi' an Shannxi,Xi'an university of architecture and technology,2011. 